\title{
STRATEGI PEMASARAN SUSU KAMBING DI ADILLA GOAT FARM DESA JERUKSAWIT KECAMATAN GONDANGREJO KABUPATEN KARANGANYAR
}

\author{
Haidar Ischak, Suprapti Supardi, Minar Ferichani \\ Program Studi Agribisnis Fakultas Pertanian Universitas Sebelas Maret \\ J1. Ir. Sutami No. 36 A Kentingan Surakarta 57126 Telp./ Fax.(0271) 637457 \\ E-mail: haidarischak@gmail.com
}

\begin{abstract}
This research aims to identify the internal and external factors in the marketing of Adilla Goat Farm's milk, formulate alternative marketing strategies, and priority strategies that can be applied in the marketing of Adilla Goat Farm's milk. The basic method used in this research is descriptive analytic. Data analysis methods using matrix Internal External (IE), matrix Strength, Weakness, Opportunity, and Threat (SWOT), and Quantitative Strategic Planning Matrix (QSP). The results showed that the alternative strategies can be used by Adilla Goat Farm in the marketing of goat milk is a strategy to make agrotourism farm dairy goats for children to be more familiar with the benefits of goat's milk early, utilizing the waste from the goats to be processed/sold, worked together with other goat breeders in the group to expand the market, make financial governance training and marketing management, making another product innovation from the goat milk, provide training for workers to be able to market the products of goat's milk, and the expansion of product marketing through promotions and advertising intensively to make it more widely known. Priorities strategy that can be used by Adilla Goat Farm is the expansion of product marketing through promotions and advertising intensively to make it more widely known.
\end{abstract}

Keywords: strategy, marketing, goat milk

\begin{abstract}
Abstrak: Penelitian ini bertujuan untuk mengidentifikasi faktor internal dan eksternal dalam pemasaran susu kambing di Adilla Goat Farm, merumuskan alternatif strategi pemasaran, dan prioritas strategi yang dapat diterapkan dalam pemasaran susu kambing di Adilla Goat Farm. Metode dasar yang digunakan dalam penelitian ini adalah deskriptif analitik. Metode analisis data menggunakan analisis matriks Internal External (IE), matriks Strenght, Weakness, Opportunity, and Threat (SWOT), dan matriks Quantitative Strategic Planning (QSP). Hasil penelitian menunjukan bahwa alternatif strategi yang dapat digunakan oleh Adilla Goat Farm dalam memasarkan susu kambing adalah strategi membuat agrowisata peternakan kambing perah untuk anak-anak agar lebih mengenal manfaat susu kambing sejak dini, memanfaatkan limbah dari hasil ternak kambing untuk diolah/dijual, menjalin kerja sama dengan sesama peternak kambing dalam bentuk kelompok untuk memperluas pasar, pelatihan tata kelola keuangan dan manajemen pemasaran, membuat inovasi produk lain dengan bahan baku susu kambing, mengadakan pelatihan untuk tenaga kerja agar bisa ikut memasarkan produk susu kambing, perluasan pemasaran produk melalui promosi dan periklanan secara intensif agar lebih dikenal masyarakat luas. Prioritas strategi yang dapat dilakukan Adilla Goat Farm dalam memasarkan susu kambing adalah strategi perluasan pemasaran produk melalui promosi dan periklanan secara intensif agar lebih dikenal masyarakat luas.
\end{abstract}

Kata kunci: strategi, pemasaran, susu kambing 


\section{PENDAHULUAN}

Susu kambing adalah susu yang dihasilkan oleh kambing betina setelah melahirkan, dalam jangka waktu 0-3 hari dihasilkan susu kolostrum yang mengandung sangat banyak zat gizi jika dibandingkan dengan susu sapi. Susu kambing pun biasanya dikonsumsi sekadarnya saja, atau lebih karena susu ini dianggap mampu menyembuhkan berbagai jenis penyakit, oleh karena itu Susu kambing juga disebut sebagai produk minuman fungsional (functional drink), dimana konsumen membeli khasiat yang terdapat pada susu kambing bukan membeli sekedar minuman susu. Susu kambing mengandung sumber protein yang terbaik setelah telur dan hampir setara dengan ASI. Moeljanto dan Wiryanta (2002:6) menyatakan bahwa manfaat susu kambing mempunyai antiseptik alami dan dapat membantu menekan pembiakan bakteri dalam tubuh. Protein lembut dan efek laksatifnya ringan sehingga tidak menyebabkan diare bagi pengonsumsinya. Susu kambing juga dianjurkan dikonsumsi untuk pertumbuhan bayi, ibu hamil, menyusui, orang tua, dan untuk penyembuhan berbagai penyakit serta kecantikan kulit (Mulyadi, 2015:111).

Pemasaran menjadi problem klasik dari setiap hasil proses produksi, tidak hanya susu kambing tetapi hampir berlaku juga bagi produk maupun jasa lainnya. Pemasaran merupakan ujung tombak perusahaan. Oleh karena itu seorang pemasar dituntut untuk memahami permasalahan pokok di bidangnya dan menyusun strategi agar dapat mencapai tujuan perusahaan (Sunyoto, 2012:18). Strategi secara umum merupakan proses penentuan rencana para pemimpin puncak yang fokus terhadap tujuan jangka panjang organisasi, disertai penyusunan suatu cara atau upaya bagaimana agar tujuan tersebut dapat dicapai. Secara khusus strategi adalah tindakan yang bersifat incremental (senantiasa meningkat) dan terus-menerus, serta dilakukan berdasarkan sudut pandang tentang apa yang diharapkan oleh para pelanggan di masa depan. Strategi pemasaran adalah logika pemasaran, dan berdasarkan itu, unit bisnis diharapkan untuk mencapai sasaran-sasaran pemasarannya. pemasaran dari perusahaan, bauran pemasaran, dan alokasi pemasaran dalam hubungannya dengan keadaan lingkungan yang diharapkan dalam kondisi persaingan.

Susu kambing yang dihasilkan oleh Adilla Goat Farm memiliki kualitas dan manfaat yang sangat baik dan memiliki nilai jual yang sangat prospektif, namun masih banyak masyarakat yang belum mengetahui manfaat yang terkandung pada susu kambing. Selain itu permasalahan yang dihadapi oleh Adilla Goat Farm yakni kurangnya tenaga manajer pemasaran yang dapat menghambat jalannya pemasaran. Perbaikan sistem pemasaran dan pembuatan strategi pemasaran yang tepat merupakan salah satu solusi dari masalah tersebut. Untuk itu diperlukan suatu strategi pemasaran agar produk susu kambing di Adilla Goat Farm Desa Jeruksawit Kecamatan Gondangrejo Kabupaten Karanganyar ini dapat unggul di pasarnya.

Penelitian ini memiliki tujuan untuk mengidentifikasi kekuatan, kelemahan, peluang, dan ancaman pemasaran, merumuskan alternatif strategi pemasaran, dan menentukan prioritas strategi yang dapat diterapkan dalam pemasaran susu kambing di Adilla Goat Farm Desa Jeruksawit Kecamatan Gondangrejo Kabupaten Karanganyar.

\section{METODE PENELITIAN}

Metode dasar yang digunakan dalam penelitian ini adalah metode deskriptif analitik. Penentuan tempat penelitian ini dilakukan secara sengaja (purposive). Informan yang digunakan untuk menggali data dalam penelitian adalah informan kunci (key informan). Penentuan Key Informan menggunakan cara purposive. Teknik pengumpulan data dengan teknik wawancara, observasi dan pencatatan. Metode analisis data yang digunakan dalam penelitian ini, yaitu: Analisis Faktor Internal dan Faktor Eksternal. Faktor internal yang dianalisis meliputi produksi, keuangan, sumber daya, dan pemasaran. Faktor internal ini kemudian dianalisis menggunakan matriks IFE (Internal Factor Evaluation). Faktor eksternal yang dianalisis meliputi pemasok, sosial budaya, kebijakan pemerintah, konsumen, dan pesaing. Faktor eksternal ini kemudian dianalisis menggunakan matriks EFE (External Factor Evaluation); SWOT merupakan identifikasi berbagai faktor secara sistematis untuk merumuskan alternatif strategi. Analisis ini 
didasarkan pada logika yang dapat memaksimalkan kekuatan (Strengths) dan peluang (Opportunities), namun secara bersamaan dapat meminimalkan kelemahan (Weaknesses) dan ancaman (Threats) (Rangkuti, 1997:31); QSPM (Quantitative Strategic Planning Matrix) yang bertujuan untuk memperoleh strategi prioritas dari alternatif strategi yang ada.

\section{HASIL DAN PEMBAHASAN}

\section{Analisis Lingkungan Internal dan Eksternal Pemasaran Susu Kambing di Adilla Goat Farm}

Identifikasi faktor-faktor lingkungan internal dalam pemasaran susu kambing menghasilkan kekuatan dan kelemahan dalam pemasaran sedangkan identifikasi faktor-faktor lingkungan eksternal menghasilkan peluang dan ancaman.

Secara umum, hasil perhitungan matriks IFE (Internal Factor Evaluation) pada Tabel 1 menunjukkan total nilai tertimbang faktor internal kunci adalah sebesar 2,7934. Berdasarkan nilai skor matriks IFE tersebut mengidentifikasikan bahwa faktor internal berada dalam posisi kuat karena berada diatas 2,5 (David, 2010:230). Hal ini menunjukkan bahwa Adilla Goat Farm telah mampu memanfaatkan kekuatan untuk mengatasi kelemahan dalam memasarkan produknya, sedangkan hasil perhitungan matriks EFE (Eksternal Factor Evaluation) pada table 2 menunjukkan total nilai tertimbang faktor eksternal kunci adalah sebesar 2,8749. Berdasarkan nilai skor matriks EFE tersebut mengidentifikasikan bahwa faktor eksternal berada dalam posisi kuat karena berada di atas 2,5 (David, 2010:159). Hal ini mengidentifikasikan bahwa Adilla Goat Farm kuat dalam memanfaatkan peluang yang ada dan mampu mengantisipasi ancaman dalam memasarkan susu kambing.

\section{Matriks Internal Eksternal (IE)}

Berdasarkan perolehan hasil dari Matriks IFE dan EFE, maka dapat disusun Matriks IE (Internal-Eksternal Matrix) untuk mengetahui posisi perusahaan yang dapat merumuskan posisi dan stategi yang dibutuhkan dalam pemasaran susu kambing di Adilla Goat Farm. Pada sumbu x dari Matriks IE, skor bobot IFE sebesar 2,7934 sedangkan pada sumbu y dari Matriks IE, skor bobot EFE sebesar 2,8749 yang menunjukkan posisi Adilla Goat Farm berada pada sel $\mathrm{V}$, yaitu menjaga dan mempertahankan. Jika digambarkan ke dalam Matriks IE, maka posisi Adilla Goat Farm dapat dilihat pada Gambar 1.

Tabel 1. Matriks Internal Factor Evaluation (IFE) Pemasaran Susu Kambing di Adilla Goat Farm

\begin{tabular}{lccc}
\hline Faktor Internal & Bobot & Rating & Skor Bobot \\
\hline Kekuatan & & & \\
1. Populasi ternak kambing yang cukup & 0.1025 & 4 & 0,4100 \\
2. Produksi susu yang melimpah & 0,1025 & 4 & 0,4100 \\
3. Permodalan yang cukup & 0,0769 & 3 & 0,2307 \\
4. Jumlah tenaga kerja yang cukup & 0,1025 & 4 & 0,4100 \\
5. Memiliki tempat yang strategis dalam memasarkan susu & 0,1025 & 4 & 0,4100 \\
kambing & 0,0769 & 3 & 0,2307 \\
6. Varian/rasa produk yang beragam & & & \\
Kelemahan & 0,0769 & 2 & 0,1538 \\
1. Kandang belum sesuai dengan standar & 0,0769 & 1 & 0,0769 \\
2. Tidak adanya pembukuan yang jelas & 0,1025 & 2 & 0,2050 \\
3. Tenaga kerja kurang berpengalaman dan bertanggungjawab & 0,0769 & 2 & 0,1538 \\
4. Harga susu kambing lebih tinggi daripada pesaing & 0,1025 & 1 & 0,1025 \\
5. Promosi dan periklanan belum maksimal & 1 & & 2,7934 \\
\hline Jumlah & &
\end{tabular}

Sumber : Analisis Data Primer, 2016 
Haidar Ischak, Suprapti Supardi, Minar Ferichani : Strategi Pemasaran Susu ...

Tabel 2. Matriks Eksternal Factor Evaluation (EFE) Pemasaran Susu Kambing di Adilla Goat Farm

\begin{tabular}{lccc}
\hline Faktor Eksternal & Bobot & Rating & Skor Bobot \\
\hline Peluang & & & \\
1. Hubungan yang baik dengan masyarakat sekitar & 0,0625 & 2 & 0,1250 \\
2. Pemerintah siap mendukung apabila diperlukan & 0,0312 & 1 & 0,0312 \\
3. Konsumen berasal dari semua kalangan & 0,1250 & 4 & 0,5000 \\
4. Jumlah produksi pesaing lebih rendah & 0,1250 & 4 & 0,5000 \\
5. Hubungan yang baik dengan pesaing/sesama peternak & 0,1250 & 4 & 0,5000 \\
$\quad$ kambing & & & 0.1250 \\
Ancaman & & & 0,3750 \\
1. Pasokan bahan pakan hijauan kurang saat musim kemarau & 0.0625 & 2 & 0,1250 \\
2. Aroma susu kambing yang masih asing untuk masyarakat & 0,1250 & 3 & 0,5000 \\
3. Harga produk susu kambing pesaing lebih murah & 0,1250 & 1 & 0,0937 \\
4. Promosi dan periklanan dari pesaing lebih maksimal & 0,1250 & 4 & 2,8749 \\
5. Teknologi yang dimiliki pesaing lebih canggih & 0,0937 & 1 & \\
\hline Jumlah & 1 & & \\
\hline
\end{tabular}

Sumber : Analisis Data Primer, 2016

\begin{tabular}{|c|c|c|c|}
\hline & $\begin{array}{ll} & \text { Kuat } \\
4,0-3,0 & \end{array} 2,9$ & $\begin{array}{l}\text { al Skor IFE } \\
\text { Rata- rata }\end{array}$ & $99-1,0^{\text {Lemah }}$ \\
\hline $\begin{array}{l}\text { Tinggi } \\
4,0-3,0\end{array}$ & $\begin{array}{c}\text { I } \\
\text { Tumbuh } \\
\text { dan Membangun }\end{array}$ & \begin{tabular}{l|l} 
& II \\
T & umbuh \\
Dan & Membangun
\end{tabular} & $\begin{array}{c}\text { III } \\
\text { Menjaga dan } \\
\text { Mempertahankan }\end{array}$ \\
\hline $\begin{array}{c}\text { Total Skor } \\
\text { EFE }\end{array}$ & $\begin{array}{c}\text { IV } \\
\text { Tumbuh } \\
\text { dan Membangun }\end{array}$ & \begin{tabular}{c|c} 
& V \\
Mehjaga dan \\
Mem ertahankan
\end{tabular} & $\begin{array}{c}\text { VI } \\
\text { Panen atau } \\
\text { Disvestasi }\end{array}$ \\
\hline $\begin{array}{l}\text { Rata- rata } \\
2,99-2,0\end{array}$ & $\begin{array}{c}\text { VII } \\
\text { Menjaga dan } \\
\text { Mempertahankan }\end{array}$ & $\begin{array}{c}\text { VIII } \\
\text { Panen atau } \\
\text { Disvestasi }\end{array}$ & $\begin{array}{c}\text { IX } \\
\text { Panen atau } \\
\text { Disvestasi }\end{array}$ \\
\hline & & & \\
\hline
\end{tabular}

$1,99-1,0$

Gambar 1. Matriks Internal-Eksternal (IE) Adilla Goat Farm

Pada sel ini, strategi yang dapat dilakukan adalah strategi intensif yaitu penetrasi pasar yang meliputi penambahan jumlah tenaga penjualan, peningkatan pengeluaran untuk iklan, penawaran produkproduk promosi penjualan secara ekstensif atau pelipatgandaan upaya pemasaran dan strategi pengembangan produk yang mengupayakan peningkatan penjualan dengan cara memperbaiki produk yang ada atau membuat produk baru yang sejenis (David, 2010:345).

\section{Matriks Strenght, Weakness, Opportunities, Threath (SWOT)}

Matriks SWOT merupakan alat pencocokan yang penting untuk mengembangkan 4 tipe strategi, yaitu SO (Strenght-Opportunities), WO (Weakness-Opportunities), ST (StrenghtThreath), dan WT (Weakness-Threath). Perumusan masing-masing strategi mengacu kepada posisi perusahaan pada matriks IE. Matriks SWOT pemasaran susu kambing di Adilla Goat Farm terdapat pada Table 3. 
Tabel 3. Matriks SWOT Pemasaran Susu Kambing di Adilla Goat Farm

\begin{tabular}{|c|c|c|}
\hline & $\begin{array}{l}\text { Kekuatan }(\mathbf{S}) \\
\text { 1. Populasi ternak kambing } \\
\text { yang cukup } \\
\text { 2. Produksi susu yang } \\
\text { melimpah } \\
\text { 3. Permodalan yang cukup } \\
\text { 4. Jumlah tenaga kerja yang } \\
\text { cukup } \\
\text { 5. Memiliki tempat yang } \\
\text { strategis dalam } \\
\text { memasarkan susu kambing } \\
\text { 6. Varian/rasa produk yang } \\
\text { beragam }\end{array}$ & $\begin{array}{l}\text { Kelemahan }(\mathbf{W}) \\
\text { 1. Kandang belum sesuai dengan } \\
\text { standar untuk kambing perah } \\
\text { 2. Tidak adanya pembukuan yang } \\
\text { jelas } \\
\text { 3. Tenaga kerja kurang } \\
\text { berpengalaman dan bertanggung } \\
\text { jawab } \\
\text { 4. Harga susu kambing lebih tinggi } \\
\text { daripada pesaing } \\
\text { 5. Promosi dan periklanan belum } \\
\text { maksimal }\end{array}$ \\
\hline \begin{tabular}{ll} 
1. & \multicolumn{1}{c}{ Peluang $(\mathbf{O})$} \\
dengan man yang baik \\
2.
\end{tabular} & \begin{tabular}{ll}
\multicolumn{1}{c}{ SO } \\
a. & Membuat agrowisata \\
peternakan kambing perah \\
untuk anak-anak agar \\
lebih mengenal manfaat \\
susu kambing sejak dini \\
(S1, S2, S3, S4, O1, O3) \\
b. \\
Memanfaatkan limbah \\
dari hasil ternak kambing \\
untuk diolah/dijual \\
(S1, S4, O1, O2, O5)
\end{tabular} & 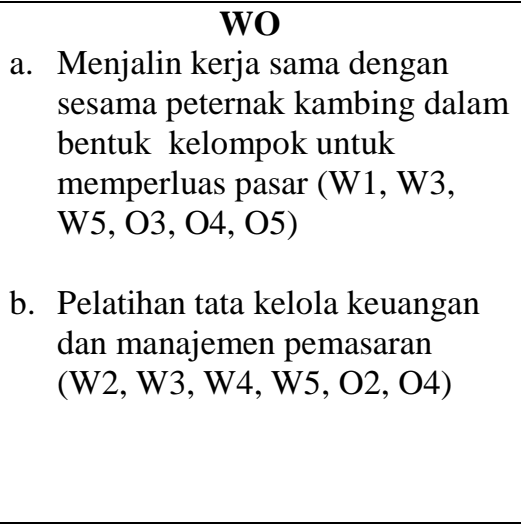 \\
\hline $\begin{array}{l}\text { Ancaman }(\mathbf{T}) \\
\text { 1. } \\
\begin{array}{l}\text { Pasokan bahan pakan } \\
\text { hijauan kurang saat musim } \\
\text { kemarau }\end{array} \\
\text { 2. Aroma susu kambing yang } \\
\text { masih asing untuk } \\
\text { masyarakat }\end{array}$ & \begin{tabular}{ll}
\multicolumn{1}{c}{ ST } \\
a. & Membuat inovasi produk \\
lain dengan bahan baku \\
susu kambing \\
$(\mathrm{S} 1, \mathrm{~S} 2, \mathrm{~S} 5, \mathrm{~S} 6, \mathrm{~T} 2, \mathrm{~T} 5)$ \\
b. \\
Mengadakan pelatihan \\
untuk tenaga kerja agar \\
bisa ikut memasarkan \\
produk susu kambing \\
(S2, S3, S4, T2, T3, T4)
\end{tabular} & \begin{tabular}{ll}
\multicolumn{1}{c}{ WT } \\
a. & Perluasan pemasaran produk \\
melalui promosi dan periklanan \\
secara intensif agar lebih dikenal \\
masyarakat luas (W4, W5, T2, \\
T3, T4, T5)
\end{tabular} \\
\hline
\end{tabular}

Sumber : Analisis Data Primer, 2016

Berdasarkan Tabel 3 diketahui alternatifalternatif strategi yang selanjutnya ditempuh dengan menggunakan taktik sebagai alat implementasinya. Alternatif strategi pemasaran susu kambing di Adilla Goat Farm, antara lain :

Membuat agrowisata peternakan kambing perah untuk anak-anak agar lebih mengenal manfaat susu kambing sejak dini

Dengan memanfaatkan pengetahuan tentang ternak kambing yang dimiliki oleh pemilik juga dapat memberikan edukasi bagi anak-anak agar mereka mengetahui manfaat apa saja yang terkandung dalam susu kambing dan tertarik untuk mengonsumsi susu kambing sejak dini. Dari agrowisata yang diadakan ini pun sekaligus akan memasarkan produk susu kambing yang dihasilkan oleh Adilla Goat Farm sendiri baik untuk anak-anak pengunjung maupun orangtua yang menemani anak-anak tersebut.

Memanfaatkan limbah kotoran dari hasil ternak kambing untuk diolah/dijual

Limbah yang selama ini hanya dibuang begitu saja alangkah baiknya apabila mulai dimanfaatkan baik dengan diolah sendiri dengan memanfaatkan tenaga kerja yang cukup 
maupun dijual, karena banyak manfaat dari limbah kambing sendiri antara lain adalah untuk dibuat menjadi pupuk organik menggunakan kotoran kambing, serta pupuk organik cair menggunakan urine kambing dimana pupuk organik ini sangat berguna untuk meningkatkan kandungan unsur hara yang dibutuhkan tanaman, meningkatkan produktivitas tanaman, merangsang pertumbuhan akar, batang, serta daun, dan juga dapat menggemburkan dan menyuburkan tanah.

\section{Menjalin kerja sama dengan sesama peternak kambing dalam bentuk kelompok untuk memperluas pasar}

Pemasaran membutuhkan biaya untuk promosi, perencanaan pasar yang dituju, dan pengemasan. Kekosongan tenaga kerja professional di bidang pemasaran pada Adilla Goat Farm dapat diminimalisir dengan membentuk kelompok produsen susu kambing di wilayah sekitar. Upaya ini dilakukan atas dasar adanya hubungan yang baik antar produsen susu kambing yang berpotensi untuk saling melengkapi kekosongan, kekurangan, dan bertukar informasi antar peternak kambing perah, dan juga karena susu kambing sendiri masih memiliki pesaing lain seperti susu sapi dan susu kedelai.

\section{Pelatihan tata kelola keuangan dan manajemen pemasaran \\ Tata kelola keuangan dan manajemen pemasaran dari sebagian besar produsen belum melakukan pembukuan maupun perencanaan keuangan dan pemasaran. Keterlibatan dan dukungan pemerintah dibutuhkan dalam bentuk penyuluhan, pelatihan, dan pembinaan.}

\section{Membuat inovasi produk lain dengan bahan baku susu kambing}

Keinovasian adalah pikiran tentang keterbukaan untuk gagasan baru sebagai aspek budaya perusahaan, sedangkan kapasitas untuk berinovasi adalah kemampuan perusahaan untuk menggunakan atau menerapkan gagasan, proses/produk baru secara berhasil. Susu kambing dapat dapat diinovasikan dengan diolah menjadi berbagai macam produk, diantaranya adalah produk susu bubuk, keju, es krim, karamel atau kembang gula, dodol susu, dan kefir.
Mengadakan pelatihan untuk tenaga kerja agar bisa ikut memasarkan produk susu kambing

Adilla Goat Farm perlu memanfaatkan tenaga kerja yang dimilikinya untuk mempromosikan dan memasarkan produk susu kambing, atau minimal dapat memberikan edukasi dengan mensosialisasikan manfaat susu kambing bagi keluarganya sendiri, teman-temannya, dan kerabatnya.

Perluasan pemasaran produk melalui promosi dan periklanan secara intensif agar lebih dikenal masyarakat luas

Promosi dan periklanan merupakan hal yang sangat penting, karena bagaimanapun tingginya kualitas maupun kuantitas produk yang dihasilkan, apabila tidak dipromosikan dan diiklankan dengan baik maka akan sulit untuk menjualnya. Promosi bisa dilakukan dengan memberikan potongan harga (discount) khusus apabila konsumen membeli susu kambing dalam jumlah yang banyak. Kemudian periklanan sangatlah mudah untuk diapikasikan di zaman yang serba modern seperti sekarang ini, hampir semua orang mempunyai telepon genggam (handphone) bahkan ponsel pintar (smartphone). Bukan hanya itu, hampir semua orang juga menggunakan media sosial sebagai tempat berbagi informasi.

\section{Matriks QSPM}

Analisis matriks SWOT menghasilkan tujuh alternatif strategi yang dapat diterapkan dalam pemasaran susu kambing di Adilla Goat Farm. Ketujuh stategi tersebut selanjutnya dipilih tiga strategi yang paling sesuai dengan kebutuhan Adilla Goat Farm. Penentuan prioritas strategi pemasaran dilakukan dengan analisis matriks QSP yang dapat dilihat pada Tabel 4.

Berdasarkan hasil analisis QSP, total nilai daya tarik tertinggi adalah strategi III sebesar 6,1608. Strategi III merupakan strategi perluasan pemasaran produk melalui promosi dan periklanan secara intensif agar lebih dikenal masyarakat luas. Stategi dengan total nilai daya tarik tertinggi mengindikasikan bahwa strategi tersebut terpilih sebagai strategi terbaik yang dapat dilaksanakan terlebih dulu dalam pemasaran susu kambing di Adilla Goat Farm. Selain strategi tersebut, strategi lain yang dapat dilakukan adalah strategi II yakni membuat inovasi produk lain dengan bahan 
baku susu kambing dengan total nilai daya tarik sebesar 5,8719, dan kemudian adalah strategi I yakni membuat agrowisata peternakan kambing perah untuk anak-anak agar lebih mengenal manfaat susu kambing sejak dini dengan total nilai daya tarik sebesar 5,8689.

Tabel 4. Matriks QSP Pemasaran Susu Kambing di Adilla Goat Farm

\begin{tabular}{|c|c|c|c|c|c|c|c|}
\hline \multirow{3}{*}{ Faktor Kunci } & \multirow{3}{*}{ Bobot } & \multicolumn{6}{|c|}{ Alternatif Strategi } \\
\hline & & \multicolumn{2}{|c|}{ Strategi I } & \multicolumn{2}{|c|}{ Strategi II } & \multicolumn{2}{|c|}{ Strategi III } \\
\hline & & AS & TAS & AS & TAS & AS & TAS \\
\hline \multicolumn{8}{|l|}{ Peluang } \\
\hline Hubungan yang baik dengan masyarakat sekitar & 0,0625 & 4 & 0,2500 & 3 & 0,1875 & 2 & 0,1250 \\
\hline Pemerintah siap mendukung apabila diperlukan & 0,0312 & 1 & 0,0312 & 2 & 0,0624 & 3 & 0,0936 \\
\hline Konsumen berasal dari semua kalangan & 0,1250 & 3 & 0,3750 & 2 & 0,2500 & 4 & 0,5000 \\
\hline Jumlah produksi pesaing lebih rendah & 0,1250 & 4 & 0,5000 & 2 & 0,2500 & 3 & 0,3750 \\
\hline $\begin{array}{l}\text { Hubungan yang baik dengan pesaing/sesama } \\
\text { peternak kambing }\end{array}$ & 0,1250 & 2 & 0,2500 & 4 & 0,5000 & 3 & 0,3750 \\
\hline \multicolumn{8}{|l|}{ Ancaman } \\
\hline $\begin{array}{l}\text { Pasokan bahan pakan hijauan kurang saat musim } \\
\text { kemarau }\end{array}$ & 0,0625 & 2 & 0,1250 & 1 & 0,0625 & 4 & 0,2500 \\
\hline $\begin{array}{l}\text { Aroma susu kambing yang masih asing untuk } \\
\text { masyarakat }\end{array}$ & 0,1250 & 4 & 0,5000 & 3 & 0,3750 & 2 & 0,2500 \\
\hline Harga produk susu kambing pesaing lebih murah & 0,1250 & 2 & 0,2500 & 4 & 0,5000 & 3 & 0,3750 \\
\hline Promosi dan iklan dari pesaing lebih maksimal & 0,1250 & 2 & 0,2500 & 4 & 0,5000 & 3 & 0,3750 \\
\hline Teknologi yang dimiliki pesaing lebih canggih & 0,0937 & 3 & 0,2811 & 4 & 0,3748 & 2 & 0,1874 \\
\hline Total & 1 & & 2,8123 & & 3,0622 & & 2,9060 \\
\hline \multicolumn{8}{|l|}{ Kekuatan } \\
\hline Populasi ternak kambing yang cukup & 0.1025 & 4 & 0,4100 & 2 & 0,2050 & 3 & 0,3075 \\
\hline Produksi susu yang melimpah & 0,1025 & 2 & 0,2050 & 4 & 0,4100 & 3 & 0,3075 \\
\hline Permodalan yang cukup & 0,0769 & 4 & 0,3076 & 3 & 0,2307 & 2 & 0,1538 \\
\hline Jumlah tenaga kerja yang cukup & 0,1025 & 4 & 0,4100 & 2 & 0,2050 & 3 & 0,3075 \\
\hline $\begin{array}{l}\text { Memiliki tempat yang strategis dalam } \\
\text { memasarkan susu kambing }\end{array}$ & 0,1025 & 3 & 0,3750 & 4 & 0,4100 & 2 & 0,2050 \\
\hline Varian/rasa produk yang beragam & 0,0769 & 3 & 0,2307 & 2 & 0,1538 & 4 & 0,3076 \\
\hline \multicolumn{8}{|l|}{ Kelemahan } \\
\hline $\begin{array}{l}\text { Kandang belum sesuai dengan standar untuk } \\
\text { kambing perah }\end{array}$ & 0,0769 & 1 & 0,0769 & 3 & 0,2307 & 4 & 0,3076 \\
\hline Tidak adanya pembukuan yang jelas & 0,0769 & 2 & 0,1538 & 3 & 0,2307 & 4 & 0,3076 \\
\hline $\begin{array}{l}\text { Tenaga kerja kurang berpengalaman dan } \\
\text { bertanggung jawab }\end{array}$ & 0,1025 & 2 & 0,2050 & 3 & 0,3750 & 4 & 0,4100 \\
\hline $\begin{array}{l}\text { Harga susu kambing lebih tinggi daripada } \\
\text { pesaing }\end{array}$ & 0,0769 & 4 & 0,3076 & 2 & 0,1538 & 3 & 0,2307 \\
\hline Promosi dan periklanan belum maksimal & 0,1025 & 3 & 0,3750 & 2 & 0,2050 & 4 & 0,4100 \\
\hline Total & 1 & & 3,0566 & & 2,8097 & & 3,2548 \\
\hline TOTAL TAS & & & 5,8689 & & 5,8719 & & 6,1608 \\
\hline
\end{tabular}

Sumber : Analisis Data Primer, 2016 


\section{KESIMPULAN DAN SARAN}

Berdasarkan hasil penelitian strategi pemasaran susu kambing di Adilla Goat Farm Desa Jeruksawit, Kecamatan Gondangrejo, Kabupaten Karanganyar, maka diperoleh beberapa kesimpulan sebagai berikut: a) Pemasaran susu kambing yang dilakukan oleh Adilla Goat Farm masih menggunakan cara tradisional, sehingga produk susu kambing Adilla Goat Farm kurang dikenal oleh masyarakat luas, terutama masyarakat yang berada di luar Kabupaten Karanganyar dan Kota Surakarta. b) Faktor internal yang menjadi kekuatan pemasaran susu kambing di Adilla Goat Farm terdiri dari: Memiliki populasi ternak kambing yang cukup, memiliki produksi susu yang melimpah, memiliki permodalan yang cukup, memiliki jumlah tenaga kerja yang cukup, memiliki tempat yang strategis dalam memasarkan susu kambing, dan memiliki varian/rasa produk yang beragam. c) Faktor internal yang menjadi kelemahan pemasaran susu kambing di Adilla Goat Farm terdiri dari: Kandang yang dimiliki belum sesuai dengan standar untuk kambing perah, tidak adanya pembukuan yang jelas, tenaga kerja yang dimiliki kurang berpengalaman dan kurang bertanggung jawab, harga susu kambing yang ditawarkan lebih tinggi daripada pesaing, serta promosi dan periklanan yang dilakukan belum maksimal. d) Faktor eksternal yang menjadi peluang pemasaran susu kambing di Adilla Goat Farm terdiri dari: Adanya hubungan yang baik dengan masyarakat sekitar, pemerintah yang selalu siap mendukung apabila diperlukan, konsumen berasal dari semua kalangan, pesaing masih rendah jumlah produksinya, dan adanya hubungan yang baik dengan pesaing/sesama peternak kambing. e) Faktor eksternal yang menjadi ancaman pemasaran susu kambing di Adilla Goat Farm terdiri dari: Kurangnya pasokan bahan pakan hijauan saat musim kemarau, masyarakat masih asing dengan aroma susu kambing, harga produk susu kambing dari pesaing lebih murah, promosi dan periklanan yang dilakukan oleh pesaing lebih maksimal, dan pesaing memiliki teknologi yang lebih canggih dalam pengolahan susu kambing.

Alternatif strategi pemasaran yang direkomendasikan terdiri dari membuat agrowisata peternakan kambing perah untuk anak-anak agar lebih mengenal manfaat susu kambing sejak dini, membuat inovasi produk lain dengan bahan baku susu kambing, dan perluasan pemasaran produk melalui promosi dan periklanan secara intensif agar lebih dikenal masyarakat luas.

Prioritas strategi pemasaran yang direkomendasikan dalam upaya pemasaran susu kambing di Adilla Goat Farm yaitu perluasan pemasaran produk melalui promosi dan periklanan secara intensif agar lebih dikenal masyarakat luas.

Saran yang dapat diberikan untuk Adilla Goat Farm yaitu sebaiknya melakukan promosi penjualan dengan cara mengadakan promo kupon diskon, pembuatan member bagi pelanggan Adilla Goat Farm dengan bonus khusus bagi member yang tergabung, serta menggunakan media periklanan radio dan pamflet/brosur, online, pembuatan akun media sosial, pembuatan situs web (website). Hal ini dilakukan untuk menjaring konsumen dari semua kalangan secara efektif.

\section{DAFTAR PUSTAKA}

David, Fred R. 2010. Manajemen Strategis Konsep-Konsep, Terjemahan. Salemba Empat. Jakarta. Penerjemah: Dono Sunardi.

Moeljanto, Rini Damayanti dan Bernardinus T.Wahyu Wiryanta. 2002. Khasiat \& Manfaat Susu Kambing : Susu Terbaik dari Hewan Ruminansia. Agromedia Pustaka. Jakarta.

Mulyadi, Um. 2015. Panduan Terlengkap Beternak Dan Berbisnis Kambing Etawa \& Kambing Lokal. FlashBooks. Yogyakarta.

Rangkuti, Freddy. 1997. Analisis SWOT Teknik Membedah Kasus Bisnis: Berorientasi Konsep Perencanaan Strategis Untuk Menghadapi Abad 21. PT Gramedia. Jakarta.

Sunyoto, Danang. 2012. Dasar-Dasar Manajemen Pemasaran (Konsep, Strategi, dan Kasus). CAPS. Yogyakarta. 